\title{
The coup that failed: An eyewitness
}

\section{account}

By Robert P. Holley

Associate Dean

Wayne State University and Martha J. Spear

Library Media Specialist

Berkley High School, Berkley, Michigan

\section{The 1991 IFLA Conference becomes an affair to remember.}

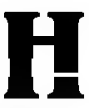

ave you heard the news?" "What news?" I replied. "Gorbachev is out." With these brief words on Monday morning, August 19, I knew that the 1991 Moscow IFLA Conference had become a special event long to be remembered in library history. For the first time ever, a political coup took place during IFLA's annual conference.

Despite the political upheaval, the conference went on almost as planned. Some meetings were shortened or rescheduled. Speakers, hastily leaving for home, made it necessary to cancel several Thursdayworkshops. A post-conference seminar in Tallin, Estonia, didn't take place. For many delegates the most unpleasant practical result may have been the lack of wine Tuesday night for the reception at the Pushkin Art Museum. Delivering wine was low priority as tanks rolled through the streets.

I especially admire the Moscow Organizing Committee for its successful efforts to keep the conference on track. Though worried about family, friends, and the fate of their country, they wanted to make sure that their foreign guests were inconvenienced as little as possible. To my knowledge, our Soviet hosts cancelled only one social event-a visit to the Moscow State University on Thursday night.

I can only guess at the feverish activity of the IFLA officers as they debated what to do. Some delegates faulted them for telling us so little during the early hours of the coup. The first announcement came from Hans-Peter Geh, IFLA President, at the Opening Ceremony on Monday afternoon. He had consulted with the Minister of Culture, Mr. Gubenko, who assured IFLA that the conference could go on with no danger to the delegates. On future days, noon was the hour when the official IFLA communique appeared on the main bulletin board with announcements of developments.

The psychological repercussions were much worse than the practical effects. It's hard to describe how little we knew. While the Conference Center was less than ten minutes' walking distance from the Russian Parliament, which became the center of activity as Yeltsin resisted the coup, I didn't know what was happening most of the time.

My wife and I had rented a Russian apartment toward the outskirts of Moscow where life went on

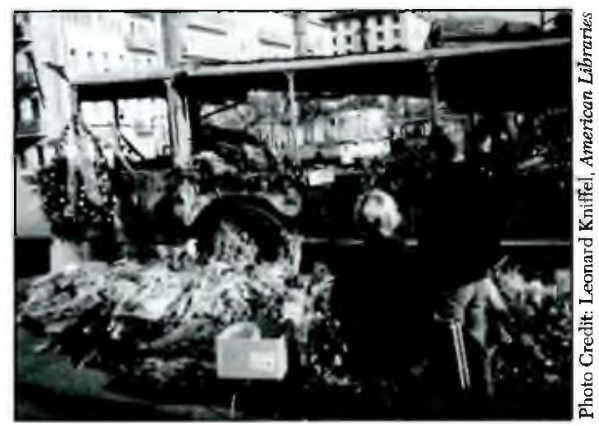

A memorial was made of the site where three young men died defending the barricade around the Parliament building in Moscow.

pretty much as normal. The street vendors hawked their wares. People rushed to catch the next subway train. The apartment had a television set and radio, but they didn't help. Even if we had understood 
my librarian spouse, learned about the coup on the Monday morning tour of Red Square and the Kremlin. Here is her story.

"The news was whispered through the tour group as the guide lectured on the history of St. Basil's Cathedral. Someone finally asked the guide about the news. She said she had been awakened in the middle of the night by a telephone call from a friend. Her friend had just heard it on the radio. It was, she thought, a peaceful transfer of power. Gorbachev was sick and recuperating at his vacation spot in the Crimea. Other than that, she knew nothing. She said she felt sad because she liked Gorbachev but that he was a 'weak' man.

"At the tour's close, I retrieved my checked backpack and prepared to head to the Rossiya Hotel for the Opening Ceremonies. I joined several fellow tour-takers going in my direction. We began to walk around Red Square when a woman said, "That sounds like tanks.' We turned and, indeed, saw tanks. Looking around, I saw mobs of people rumning in the direction of the Kremlin. Streetcars stopped in their tracks and their occupants poured out. As the crowds ran in one direction, I was determined to go in the other, toward the Rossiya. I felt as if I were in a parade-going the wrong way. We heard gunfire. In crossing one intersection, I passed in front of a parked bus filled with armed soldiers. I imagined the bus doors openingand their pilingout. If shooting began, I would be in the cross-fire. I worried about my husband and wanted him with me. (He was, in fact, conducting his own cross-town journey to the U.S. Embassy.) I worried about my passport; I had given it to the conference organizers for the authorities to stamp. I worried that my IFLA badge, a magic talisman in hotels and hard-currency stores, would not be enough to stop the bullets. In my mind, I heard my dying words: 'Tourista!'

"Even so, in the midst of the bodies and confusion, I saw old women in queues to buy meat. We made it to the Rossiya where I peacefully ate a roll and cup of coffee for lunch."

Meanwhile, I was registering my address at the U.S. Embassy. When I objected to going there, other Americans handed me a form from the supply acquired during their earlier visit and told me how important it was. I filled out the form as best I could. I didn't have my passport number because it was with the Soviet police for visa registration, a step required by law if a visitor wished successfully to pass exit security. (I was worried about not having my passport in case events took a turn for the worse.) The private apartment had a telephone, but I had no idea what the number was. At best I had a minimal street address, but I doubt that the embassy could have found me.

Three of us then decided to share a cab. Turned back by the crowds at the Russian Parliament, the taxi driver found a roundabout way to cover the short distance to the embassy. As Americans we quickly got in, passed through security, and handed in our completed forms. The embassy employee told us that he lacked details beyond what was known from the Western media and gave us a stern waming to stay out of trouble.

Our difficulties then began. Two of us wanted to attend the opening ceremonies at the Hotel Rossiya on the other side of Red Square. I especially needed to be there because l'd promised to meet my wife. After we flagged a taxi with some difficulty, the driver couldn't get through. Even changing the destination to the Conference Center didn't help because he was then mired in the massive traffic jam. Deciding to try another alternative, we gave the friendly driver $\$ 6.00$ for his troubles, a great sum where agood monthlywage is $\$ 70$. By now it was too far to walk to the Rossiya. Fortunately, I had my detailed map of Moscow (produced, I heard, by the CIA without a title page to hide responsibility). I located the nearest subway station within a tenminute walk. Our third colleague, who wanted to get back to the Conference Center, had never taken the Metro and was worried about getting lost if he walked. Unswayed by his arguments to escort him back, the two of us pointed him in the right direction and told him to be a big boy. (He made it.) We took the next subway train and successfully arrived at the opening ceremonies with time to spare.

The opening ceremony proceeded with eerie normalcy. After the state-of-the-emergency announcement from Hans-Peter Geh, the predictable round of official speeches followed. The Min- 
ister of Culture, Mr. Gubenko, gave the opening address even as he inwardly feared perhaps for his freedom and certainly for his political career. $\mathrm{He}$ did get up and go backstage several times, the one hint that all was not normal. After a break complete with a folklore show in the lobby, we returned for a performance of the ballet "Romeo and Juliet" by Prokofiev. The world may have been crumbling about us, but the show went on. (Later in the conference, Hans-Peter Geh commented that the dancers had tears in their eyes as he gave them the congratulatory flowers.)

By Wednesday, August 21, the coup had failed. That evening we had an elaborate reception in the Palace of Congresses right in the heart of the Kremlin. As Martha describes it, "Who would have thought that only two days after the somber opening ceremonies, we would be eating and drinking and dancing within the Kremlin walls? After nearly a decade of IFLA conferences, I have seen my share of feting and merry-making. The Kremlin reception stands alone, however, in terms of its sheer energy and joy. I had a perch overlooking the center stage and most of the main floor. The entertainment consisted of folk groups, dancing girls, and an electric violinist in a mini-skirt and with chorus-girl kicks. But the main floor of conferees was where the action was. People danced in circles, conga lines, twosomes, foursomes. I watched a Russian woman dance nonstop for two hours; her energy wore out a series of male partners. A young man performed an impromptu Cossack dance. People began grabbing roses from the table centerpieces. "For independencel' someone shouted. I took a rose."

Those of us who stayed could now be smug for having made the right decision. Some with changed plane reservations had to leave though their departure was now no longer necessary. The official speeches changed from concern to congratulations on the triumph of freedom. Newly elected IFLA President Bob Wedgeworth repeated the quote from Frederick Douglass that he had propheticly included in his election speech given before the coup: "If there is no struggle, there is no progress." The Soviet Minister of Culture was greeted with a hearty round of applause when he told us that he had resigned to protest the coup. In the streets, Soviets celebrated. I heard that Bob Wedgeworth joined in as the enthusiastic crowd toppled the statue of Felix Dzerzhinsky, founder of the KGB.

Though the second voting session was cancelled, I suspect for a feared lack of quorum, the closing ceremony on Friday was the largest that I can remember; delegates had to stand in the back of the large auditorium. We shared a solidarity far beyond the usual IFLA camaraderie. The tours on Saturday all went as scheduled with only the minor inconvenience of changing the route to the Zargosk Monastery to avoid the crowds in the KGB Square.
That last Saturday night, my wife and I walked to the Russian Parliament. Bumed busses still blocked the major street from the city center. Near the Moscow River a crane was lifting the hulk of a truck into a lorry to be carried away. People, mostly young, were revisiting the site of the successful resistance. Around the back, two bulletin boards held photographs of the recent events. Though troops guarded the entrance to the Parliament building, all was now quiet. We took a few pictures, gathered a piece of charred wood from the fires that the demonstrators had used to keep warm, and walked to the subway. It was time to pack to leave for home early the next morning.

Life will not be so simple for the Soviet colleagues we left behind. History may record this coup as a turning point, but I'm sure that many events, often unexpected, will take place before relative stability returns to this part of the world. The economic outlook is grim. Democracy and intellectual freedom are not assured even if the "good guys" stay in power. If events go against him, Boris Yeltsin may react differently; his firing of the head of Tass, the Soviet news agency, is not a good sign.

My years in IFLA have taught me how lucky we American librarians are. Our difficulties are nothing compared with those of Eastern Europe, the Soviet Union, and the Third World. Myclosing wish is that the next IFLA Moscow Conference finds a peaceful and prosperous Soviet Union.

\section{Hispanic Resource Director 1992-1994 \\ By Alan Edward Schorr \\ 380p. 8 1/2 X 11 ISBN 0-938737-26-0 \\ $\$ 47.50+\$ 2.50 /$ shipping}

The most comprehensive guide to 6,200 national, state and local Hispanic onganizations, associations and govemment programs; research centers, libranes and museums; Hispanic commissions; Hispanic studies programs; educational institutions; migrant and bilingual education; migrant health; human rights; Hispanic chambers of commerce; minority \& small business; Hispanic employment programs; print and electronic media; and Latin American diplomatic offices. The best directory of those offenng services or providing information/policy analysis about Hispanics. Recommended by Library Journal, Reference Books Bulletin, RQ, Vista, American Reference Books Annual, Morgan Directory Reviews and Small Press.

\section{The Denali Press}

Post Office Box 021535

Juneau, Alaska USA 99802

(907) 586-6014 Fax (907) 463-6780 


\section{Fortunately, nothing is left to chance when you consult the sociological abstracts 5-year Cumulative Index.}

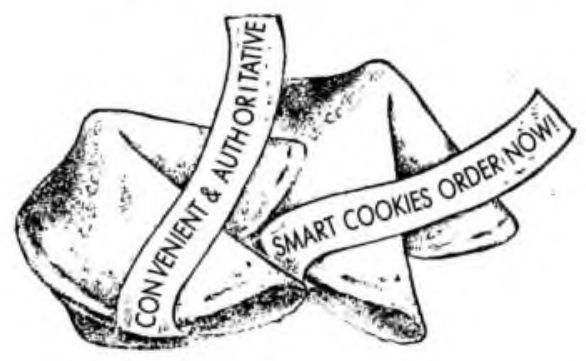

You can rely on the index for authoritative global coverage of the literature of sociology and its related disciplines.

The sa 5 -year Cumulative Index...

- brings you all Author, Source, and Subject Index entries from 1986-1990.

- Offers the convenience of single-volume Author and Source Indexes, plus a comprehensive 3-volume Subject Index.

- Uses the sa Thesaurus of Sociological Indexing Terms as the basis for all Subject Index entries, thus providing an uncomplicated method for tracking the extensive range of topics covered in the database.

- Simplifies and speeds the retrospective search process.

So, why not join the other smart cookies who are ordering the sa 5 -year Cumulative Index at the special prepublication price of $\$ 425.00$-a savings of $\$ 50.00$ over the regular subscription price. To take advantage of this limited offer, simply complete the coupon below and return it with your $\$ 425.00$ prepayment. Offer ends October 30.

\section{Act Now and Save!}

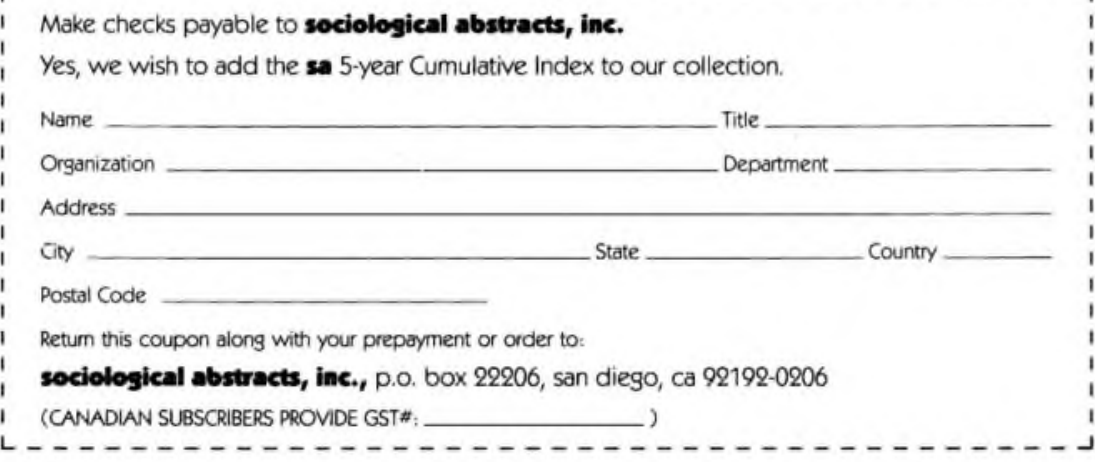

